\title{
Applying Ho Chi Minh's Thinking Style in Training Self-Study Ability of Students in Vietnam Today
}

\author{
MSc Trinh Quang Dung \\ University of Economics - University of Danang
}

\begin{abstract}
Family is a cell of society, the first social institution contributing a fairly decisive part to build personality of each person. The family's stability is the premise for the development of a civilized and wealthy society. Family organization exists and changes with the existence and change of the social life. Over the last years, Vietnamese society have seen vigorous changes in many aspects thereby Vietnamese family is in transition from traditional family to modern one. This article focuses on clarifying the concept of family, traditional Vietnamese family, features of traditional Vietnamese family, especially pointing out the changes from traditional Vietnamese family to Vietnamese family today. Ho Chi Minh was not only an outstanding cultural icon, a hero of national liberation, a great revolutionist of Vietnam, but also a shining example of self-studying and self-training. He has a unique scientific method and thinking style, that is independence, autonomy, creativity, towards new things, always stemming from objective practices, etc. Up to now these styles have remains intact and can be applied to selfstudying of students at universities in Vietnam in the current period. The paper clarifies issues on Ho Chi Minh's thinking style, characteristics of his thinking style, and applies Ho Chi Minh's thinking style to train self-study ability for university students in Vietnam today.
\end{abstract}

Keywords: Style, Ho Chi Minh's thinking style, student, self-study ability

DOI: $10.7176 /$ RHSS/9-24-04

Publication date: December $31^{\text {st }} 2019$

\section{Introduction}

Ho Chi Minh was an outstanding cultural icon, a hero of national liberation, a genius leader of the Vietnamese people, who made great contributions to many victories of the Vietnamese people. His ideas are not only a guide for the actions of the Party and Government of Vietnam, but also a valuable lesson for directing positive behaviors for every human being today. One of the most important milestones in Ho Chi Minh's operation is to leave the next generation a methodology, a unique style of thinking that is very scientific, revolutionary and progressive, which is applicable in training each individual person today.

Vietnam is one of the countries with fast growth rates in the region and in the world, this development sets the demand for using high quality human resources with full professional capacity and ethical qualities, ability to quickly integrate with the world, improve skills and one's self. Therefore, in current universities of Vietnam, besides training a highly specialized force, they also focus on many solutions to promote students' self-study and self-research abilities to turn the training process into a self-training process of students. Therefore, promoting students' self-study ability is an important activity of the schools and measures are needed to develop them.

During the development process, the Party and Government of Vietnam always emphasized the movement "Study and follow the example, style and method of Ho Chi Minh", especially with the younger generation of students - the future quality human resources, it is necessary to learn the thinking method, that style of thinking of the great President Ho Chi Minh of the nation.

\section{Materials}

Style is a familiar term in science and life, and there are many different concepts about style. Style is a term that appeared very early, derived from the Latin word - "stilus", which is considered a pen or writing in art and literature. It is a consistent, recognizable and manifested system in many subjects' statements. Until now, people also have many different views on style. According to B.A Uspenki, there are two different ways of understanding styles. In the first interpretation, "style is understood to be something that links the considered phenomena with certain other phenomena; it is understood as the manifestation of a certain system of consistency, of a common internal form within the basis of a range of phenomena investigated - in other words, in the foundation of a certain text". On the contrary, also according to this author, it's possible to understand style in another sense. It is something special, that is the literary characteristics related to the peculiarities of the text. It is in this case that people talk about the style of a writer or an artist in particular, or personal style in general" 1 . Also in this author's view, style is expressed in three main areas: first - the reader has a special impression of an expression of the author; second - from the dependency relation of style signs that are frequently used by the author in his works, meaning the style that dominates the way the author's expression is related; third - how the relationship is between

\footnotetext{
${ }^{1}$ B.A. Uspenski - Semiotics matters in light of linguistics. TZS.4 (IV). Tartu, 1969, page.487-488
} 
the concept of style and its expression outside the author's work. Thus, in this view, style is the concept and expression of the authors 'views into their works, the readers' perception of the author's distinctive signs, between elements of style closely related to each other. The style understood in this concept is that of literature and art. However, in terms of science, this view also has values, namely: asserting style is the whole conception and expression of the style subject, which is the special "imprint" of the owner, which can be perceived by the intended audience, and thereby distinguish different types of styles.

In Vietnamese dictionary, the style is understood as the way of living, working, operating, behaving to create the unique of a person or a certain class of people (in general); they are also systematic characteristics of thought and art, expressed in the composition of an artist or in works of the same genre in general; or it may be the form of the language used in certain functional requirements, different from other forms of vocabulary, grammar, and phonetic characteristics. ${ }^{1}$.

Thus, common style is understood in two areas: in a narrow sense (literary and artistic style) and style in a broad sense. But, although there are differences in scope, it can be asserted that style is systematic individual and unique characteristics (rule, style, manner, nuance, attitude, dignity, etc.), becoming a stable routine of a person or a class of people which is expressed in all aspects of activities such as labor, study, activities, behavior, expression (speaking and writing), etc., creating values, the distinctive features of that subject.

\section{Results}

\subsection{Ho Chi Minh's thinking style}

On the basis of such style perception, when studying Ho Chi Minh, it can be emphasized that Ho Chi Minh is a subject with a distinct style, showing many aspects, but one of Ho Chi Minh's most striking styles is the thinking style.

Ho Chi Minh thinking style is the whole point of view, ideology and expression of Ho Chi Minh's revolutionary and scientific thinking approach to issues of practice, thinking control, awareness and behavior in solving problems of reality. Ho Chi Minh's thinking style does not appear randomly or naturally but is the result of the creative application of the scientific methodology of previous thinkers combined with the creative and proactive capacity of thinking. Only Ho Chi Minh can inherit the traditional values and turn it into the capabilities of Ho Chi Minh. The Ho Chi Minh's thinking style has been expressed in Ho Chi Minh's works as well as in leading revolutionary practice, which is a style of inquiry, independence, autonomy and creativity based on historical empirical evidence of Vietnam; expanding thinking on the basis of research, critical inheritance of theories that exist in the history of human thought; towards the new and progressive things, expanding the view of the world to perceive theory and practice.

Ho Chi Minh is the subject of radical scientific and revolutionary thinking, which is the most distinctive feature of Ho Chi Minh's thinking. Science - that is, Ho Chi Minh always forms his own perceptions and ideas based on objective analysis and perceptions of the object, based on which measures are taken to solve a problem in the most scientific way. In Ho Chi Minh, there is no ideological, superficial and authoritarian mindset in perception. When studying phenomena, it is necessary to point out the nature of the problems and aspects of perception to ensure the objectivity and comprehensiveness of things. In addition to the scientific aspect, according to Ho Chi Minh, awareness must be a radical revolution, which is to change the old with the new. He is always in support of the new and progressive things, not obstinate and pursuits the idea of reconciling the opposites. This style of thinking is shown in the following aspects.

Firstly, it is the method of independent thinking and autonomy. In the view of Prof. Dr. Mach Quang Thang, independence, autonomy is a method of non-tailing and independent thinking, not being dependent on an opinion, a certain thought ${ }^{2}$. This view is very reasonable, because: first, Ho Chi Minh is always the one who actively explores, creates and experiences himself in order to draw theories, ideas, so in Ho Chi Minh's thought, it is never machine-like application, following every sentence, every word and these streams of thought. Second, independence and autonomy are not only Ho Chi Minh's views on thinking, but independence and autonomy are also the goals and the only destination in his revolutionary activities. Coming from a half-feudal country, Ho Chi Minh saw the great aspirations of an entire nation, the entire people, and soon contact with the outside world, Ho Chi Minh soon asserts his ideal to help the people, the country, lead people towards an "independent and autonomy" life. That ideal goal covers all cognitive activities and revolutionary leadership of Ho Chi Minh. Because, according to him, "In the world of thousands of bitter things. What is more bitter than the loss of freedom? "3. Therefore, in his whole life, Ho Chi Minh's career, independence and autonomy is the greatest desire: "I have only one desire, the utmost desire, is for our country to be completely independent, our people are completely free, everyone has food and clothing, everyone can study". For these reasons, in Ho Chi Minh's thought and actions, Ho Chi Minh always upholds the element of independence and autonomy.

\footnotetext{
${ }^{1}$ Hoang Phe, Vietnamese Dictionary, Hong Duc Publishing House, 2003, p.782

${ }^{2} \mathrm{http}: / /$ tapchiqptd.vn/vi/theo-guong-bac/phong-cach-tu-duy-ho-chi-minh/9640.html

${ }^{3}$ Ho Chi Minh, Complete volume, volume 3, Hanoi National Political Publishing House, 2011, p.366
} 
Ho Chi Minh has taken measures to implement this principle in awareness. According to him, firstly, it is necessary to learn a lot of progressive knowledge in the world, inheriting the values in the minds of humankind as well as many good traditional values of the nation. But the important thing, secondly, inheriting but not following every word, it must be summarized and summed up into its own. Even for the direct theoretical basis that influenced Ho Chi Minh - Marxism-Leninism; Ho Chi Minh also did not apply in a machine-like, hard, dogmatic way, because according to him: "understanding Marxism - Leninism is to live together with meaning. If you remember so many books but live without love, how can you claim to understand Marxism-Leninism "1. From that principle, Ho Chi Minh applies creativity in accordance with the aspirations and requirements of Vietnamese practices. For Ho Chi Minh, there is no theory that is universal, if the doctrines have the answers to Vietnam's problem, making Vietnam develop, independent and free, that doctrine is progressive. Therefore, Ho Chi Minh has converged the cultural quintessence of humankind, and inherited many positive values of traditional culture. The Soviet poet Osip Mandelstam, in late 1923, after meeting and chatting with Nguyen Ai Quoc, wrote an article on the Ogoniok (Small fire), that: "From Nguyen Ai Quoc radiated a culture, not European culture, but perhaps a future culture, etc. Through the high manner, in the warm voice of Nguyen Ai Quoc, we are like hearing tomorrow, like seeing the immense tranquility of world-wide friendship"2.

Second, Ho Chi Minh's thinking is always creative, towards new things.

Creativity, innovation is the requirement in awareness that not only recognizes dialectic relationships with each other, but also sees the development trend of phenomenal things. Ho Chi Minh always sees things phenomena in the trend of development, upward, relentless movement. It is the process of releasing all obstacles, difficulties, even difficulties within ourselves, for sustainable development. This way of thinking requires people to always adapt to all situations. To adapt, we must innovate ourselves to develop. According to Ho Chi Minh, the development process is the process of negating the old and adding new elements, it is also the process of always liberating and releasing all the constraints of backwardness to keep up with advancements.

Demonstrating this method of thinking, according to Ho Chi Minh, it is necessary to understand the laws of movement of the objective world from which to find out the development of things and phenomena, based on which Solution solutions conform to requirements and requirements of reality. To do this, you have to be creative, always new. Because, according to him, "Everyone has a good side and a bad side. Education must make the good bloom like the spring flowers and the bad will fade away" and for each one needs to pray for progress" Must learn to seek progress. Don't be arrogant, learn good things from people."3

Third, Ho Chi Minh always comes from objective reality

In Ho Chi Minh's thinking, there is always a smooth combination of reasoning with practice, reasoning with reality, reasoning formed from reality and his practical activities always follow reasoning. According to him, the relationship between theory and practice is closely related. "The reasoning is to bring reality in history, in experience, in the struggles, to examine, compare carefully, clearly and make a conclusion. Then bring it to prove it to reality. That is the true argument, etc. The reasoning that does not apply to the fact is empty reasoning. Even if you see thousands of theoretical books, you don't know how to put them into practice, it's like a chest of books... practice must be based on theory." 4

It is this concept of the relationship between reason and reality, so according to him, awareness and action must come from objective reality, taking into account specific conditions, imposing subjective demand on specific situations, do not think like machine, not far from reality.

Thus, it can be affirmed in Ho Chi Minh's thinking style to always emphasize the following principles: promoting independence, autonomy, always aiming at objectivity, progress, development and having to start from objective reality. These are also the principles in society today we can still learn, apply and follow Ho Chi Minh's style, especially for the younger generation like students in Vietnam today.

\subsection{Applying Ho Chi Minh's thinking style to training self-researching capacity for students at universities in Vietnam nowadays.}

a) Concept of students' self-learning capacity

In the fourth technological revolution that is happening strongly nowadays, one of the requirements for students at universities in Vietnam nowadays is self-learning and self-researching capacity. Self-learning capacity is the term often mentioned in educational science. Scientists think that self-learning is brainstorming, thinking using intellectual capacities (such as observation, comparison, analysis, synthesis ...) and sometimes muscles (when using the tools) and qualities, motivations, even outlook on life., worldview to comprehend a certain field of knowledge into their own property and "Learning, the key is self-learning, is an internal development process in which the subject expresses and transforms themself, enriches its value by acquiring, processing and transforming

\footnotetext{
${ }^{1}$ Ho Chi Minh, Complete volume, volume 15, Hanoi National Political Publishing House, 2011, p.668

${ }^{2}$ Ho Chi Minh, Complete volume, volume 1, Hanoi National Political Publishing House, 2011, pp.462-463

${ }^{3}$ Ho Chi Minh, Complete volume, volume 5, Hanoi National Political Publishing House, 2011, p.54

${ }^{4}$ Ho Chi Minh Toan, Complete Volume, Volume 5, National Political Publishing House, Hanoi, 2011, pp.273-274
} 
external information into knowledge within themself." ${ }^{1}$.

Capacity is the term "refers to the ability to perform successful and responsibly tasks and solve problems in defined situations as well as changing situations based on mobilization of synthetic knowledge, skills and other psychological attributes such as motivation, will, conception, values ... thorough thinking and readiness to act. "2 Thus, it can be understood that capacity is the synergy, the ability to mobilize every individual's ability to perform or solve a problem in certain circumstances.

On that basis, it can be seen that "Self-learning capacity" is the ability to mobilize a combination of different knowledge, skills and psychological attributes to perform successfully comprehend scientific knowledge, as well as successfully implement the application of learned scientific knowledge to solve practical problems.

Self-learning capacity is clearly shown in the following aspects: interest, positive level, active self-learning (positive attitude); have enough knowledge to solve scientific problems (in term of knowledge) and take measures to self-learning and self-researching logically (skills). To be able to perform self-learning ability of students and achieve good results, there should be a system of different solutions, but the most important thing is to provide students thinking strategies, orientations of self-learning, self-researching plan, because this is an activity that affects the lives of students, not only to meets the requirements at the school, but also affects the students' selflearning capacity after graduation and becoming a part of human resources in society.

b) Apply Ho Chi Minh's thinking style to the development of students' self-researching capacity in schools nowadays.

In order to train students with self- learning and self-researching thinking methods, we can apply Ho Chi Minh's thinking style. Because, Ho Chi Minh's thinking style, considered in a certain aspect, is also the way of individual thinking . Beside, thinking style of Ho Chi Minh is also influenced by the culture of the nation, of the civilizations in the world, so when applying Ho Chi Minh's thinking style in training for Vietnamese students to acquire a method of thinking, students' self-learning capacity is reasonable, with many similarities, easy to learn in awareness and easy to show in practice. Moreover, Ho Chi Minh was not only the genius leader of the Vietnamese nation, He was also a good example in self-learning and self-training, his entire revolutionary life was sharpest proof for that ideal.

Firstly, when applying Ho Chi Minh's thinking style to the self-learning activities of Vietnamese students nowadays, it is necessary to correctly identify the meaning and importance of self-learning and self-training. According to Ho Chi Minh, everyone has strengths and weaknesses, no one is perfect and comprehensive, so they must always learn and train themself. "We have to learn and operate revolution all our life. If you live, you still have to learn, you still have to operate revolution, " ${ }^{3}$,each individual is just as small as a grain of sand in the desert, so the awareness is limited, so to avoid being obsolete, they have to learn, to practice regularly, to learn for life "No one can claim to know enough, know it all. The world is changing day by day, our people are getting better and better, so we must continue to learn and practice to be better same time with the people "so that the good part of each of us" grows into trees and gradually blooms with flowers and fruits" ${ }^{4}$. In oder to do this, according to Ho Chi Minh, the key is self- learning. Education and training is not a passive transmission and acquisition process, but rather a self-training and self-learning process. "Take self-learning as a base. with discussion and direction adding on. " 5

In the today schools, the role of self-learning of students must be clearly expressed, students should not be dependent, waiting for support, help and guidance from the teachers, so from that, in the process of self-learning, new skills, knowledge and positive attitudes of students are formed and perfected. Therefore, when participating in studying at schools, students must identify the first thing is training themselves with the capacity and method of thinking in self-learning and self-researching.

Second, when studying in the Ho Chi Minh thinking style, students must determine to answer the task "Learn to do what ". According to Ho Chi Minh, learners must identify the motivation and purpose of the learning fully and properly. Answering the question "Learn to do what", Ho Chi Minh pointed out: Learn to correct ideas, learn to cultivate revolutionary morality, learn to believe in the union, in the people, in the future of the nation, the future of revolution, learn to practice. He said: "Learn to work, to be a human, to be an official. Learn to serve the mass, classes, and people, Homeland and humanity " 6 . For the purpose of that learning, everyone must have the right learning motivation to apply to practical work. Ho Chi Minh's thought on learning motivation fits perfectly with Unessco's perspective on four pillars of education: "Learn to know, learn to do, learn to live together, learn to be human". This proves that Ho Chi Minh has a deep awareness, a visionary of education in general and self-

\footnotetext{
${ }^{1}$ Nguyen Canh Toan (editor), Learning and teaching, Hanoi University of Education Publishing House, 2002, p.64

${ }^{2}$ Bernd Meier - Nguyen Van Cuong, Theory of modern teaching, the basis of renewing the objectives, content and teaching methods. University of Education Publishing House, 2006, p.68.

${ }^{3}$ Ho Chi Minh full episodes, episode 15. National Political Publishing House, Hanoi, 2011, p.113

${ }^{4}$ Ho Chi Minh full episodes, episode 15. National Political Publishing House, Hanoi, 2011, p.377

${ }^{5}$ Ho Chi Minh full episodes, episode 15. National Political Publishing House, Hanoi, 2011, p.312

${ }^{6}$ Ho Chi Minh full episodes, episode 6. National Political Publishing House, Hanoi, 2011, p208
} 
learning in particular.

In the current digital era, students of Universities in Vietnam must fully understand motivation and purpose of learning to learn and train themselves to meet the increasing demand for human resources of the domestic and worldwide labor market, at the same time, must aim at the goal of the purpose of rich people and strong country, raising the position and prestige of Vietnam in the world.

Third, learning Ho Chi Minh thinking style, students must build a sense of initiative, actively in learning, humility, passion, progressive, and not arrogance. According to Ho Chi Minh, arrogance is also a disease of " arrogance, greed for status, contemptuously, want the flattery, praise from others, want to give orders to others ". 1 "Arrogance means assuming that you can master everything and can do every, that you are better than everyone else, that you are a god, you don't need to learn from anyone". ${ }^{2}$ It is this arrogant disease that will lead to the bad consequence of being lazy to learn, blindness is enemy of the people, enemy of diligence, eventually "will definitely lead to failure". Therefore, according to Ho Chi Minh, each individual must practice humility, honesty, and keep learning regularly to make progress in all aspects.

In the process of self-learning, students must avoid laziness, parroting, arrogance to try to focus on learning, training themselves to be talented enough, have a sense of initiative in self-learning, do not be satisfied with the existing knowledge and achievements, always learning, improving, by that the self-learning effect will achieve high results. "Must be voluntarily, have self-disciplines that considering learning is also a task that revolutionary official must complete, so that, complete the study plan actively and automatically "3, "Must study even if teacher doesn't show up "4.

Fourth, learning Ho Chi Minh's thinking style in self-learning, students must identify the right thinking method and learning method. When doing self-learning and self-researching students need to master the principles of Ho Chi Minh's thinking methodology, namely:

Promote independence, autonomy in thinking and freedom in thought. This requires that when learning, researching, reading documents, students must not learn rote or learn from other people's models, they must dig deep into their thoughts, do not blindly believe, do not memorize each sentence, each word in the document. For anything students have to answer 3 questions: What is it? Why is there such a problem? And how is it? They must look at the problem holistically, find out what the researched problem is, what it means in life, they must find the causes for that problem, as well as see how does it appear in practice. When the problem is still unclear, students need to contact the lecturers, work with their classmates to debate, find out the right knowledge for the problem of self-researching. In this way, the new knowledge is truly profound, natural and close to students.

After discussing the above issues, students must also clarify the application and relate the self-researching problem to their own practice and future work. According to Ho Chi Minh, learning must be done for practicing, if you want to practice, you must know how to understand the theory, then apply it to practice, to compare, and to analyze it so that students can learn the true knowledge, students have to imagine what to do when they graduate and have jobs with that knowledge and use it. Students must remember this important principle that Ho Chi Minh emphasized, "Learning must be done together with practicing. Learning without practicing is useless. Practicing without learning also can not be smoothly. "5.

c) Some requirements for training students' self-learning and self-research capacity in universities in Vietnam today based on Ho Chi Minh thinking style.

To accomplish the task of training the students' self-learning capacity, requires lecturers at the schools to perform the following tasks: training themselves to have good pedagogical capacity and methods to guide students doing self-learning the most effective way, experience, pedagogical skills in solving situations taking place in the process of teaching and guiding students. Moreover, lecturers need to guide students' self-learning capacity, provide students with the right method and means of self-learning. At the same time, must follow each step of the student's self-learning process, provide timely support to students when they need it. In addition, lecturers should also build a system of tests and assessments to encourage students' self-learning and self-researching capacity.

On the student side: first and foremost, students must identify the purpose, the motivation and the sense of initiative in self-learning, need to practice scientific research methods effectively with good quality, need to find for themselves the thinking method, the research method that is suitable for themself. In particular, students must be creative, think up new issues, discuss with friends and teachers to get the best knowledge.

\section{Conclusion}

Imbued with the Ho Chi Minh thinking style, Vietnamese students are now striving to learn and research in order to achieve the best academic results, ready to graduate and go to work and meet the needs of the economy, world

\footnotetext{
${ }^{1}$ Ho Chi Minh full episodes, episode 5. National Political Publishing House, Hanoi, 2011,p295

${ }^{2}$ Ho Chi Minh full episodes, episode 5. National Political Publishing House, Hanoi, 2011,.p631

${ }^{3}$ Ho Chi Minh full episodes, episode 11, National Political Publishing House, Hanoi, 2011, p.98

${ }^{4}$ Ho Chi Minh full episodes, episode 6, National Political Publishing House, Hanoi, 2011, p.360

${ }^{5}$ Ho Chi Minh full episodes, episode 6, National Political Publishing House, Hanoi, 2011, p.361
} 
integration, actively promoting the role of high quality human resources for the country's development. To do that, firstly, every student in the course of learning at the University must know how to learn and train themself, and for schools, they need to continue improving the "Learn and follow Ho Chi Minh's moral example, style and method examples" in the near future so that the students' learning will achieve higher results./.

\section{REFERENCES}

1. B.A. Uspenski - Style semiotics problems in the light of linguistics. TZS.4 (IV). Tartu, 1969

2. Bernd Meier - Nguyen Van Cuong, Theory of modern teaching, the basis of renewing the objectives, content and teaching methods. University of Education Publishing House, 2006, p.68.

3. Mai Thi Lan, Promoting students' self-learning and self-researching ability according to Ho Chi Minh Thought, Journal of Education, Special Issue, May 1, 2018, pages 9-12

4. Ho Chi Minh, full episodes, episode 1, Hanoi National Political Publishing House, 2011

5. Ho Chi Minh, full episodes, episode 3, Hanoi National Political Publishing House, 2011

6. Ho Chi Minh, full episodes, episode 4, Hanoi National Political Publishing House, 2011

7. Ho Chi Minh, full episodes, episode 5, Hanoi National Political Publishing House, 2011

8. Ho Chi Minh, full episodes, episode 6, Hanoi National Political Publishing House, 2011

9. Ho Chi Minh, full episodes, episode 11, Hanoi National Political Publishing House, 2011

10. Ho Chi Minh, full episodes, episode 15, Hanoi National Political Publishing House, 2011

11. Hoang Phe, Vietnamese Dictionary, Hong Duc Publishing House, 2003

12. Nguyen Canh Toan (editor), Learning and teaching, Hanoi University of Education Publishing House, 2002

13.http://tapchiqptd.vn/vi/theo-guong-bac/phong-cach-tu-duy-ho-chi-minh/9640.html 